\title{
KEMAMPUAN MENGAPRESAISI PUISI DENGAN METODE HERMENEUTIK DALAM PENGUASAAN BAHASA FIGURATIF SISWA MAN 2 MATARAM TAHUN PELAJARAN 2018/2019
}

\section{(THE ABILITY TO APPRECIATE POETRY WITHHERMENEUTIC METHODS IN MASTERING THE FIGURATIVE LANGUAGE OF STUDENTS OF MAN 2 MATARAM IN2018/2019 ACADEMIC YEAR)}

\author{
Sukran Makmun dan Rabiyatul Adawiyah \\ Universitas Nahdlatul Wathan Mataram \\ email: sukronmakmun247@gmail.com; rabiyatula@gmail.com
}

Diterima; 11 Oktober 2018; Direvisi: 14 Oktober 2018; Disetujui: 24 November 2018

\begin{abstract}
This research is aimed to determine the ability to appreciate poetry by hermeneutic methods in mastering figurative language of students of MAN 2 Mataram in 2017/2018 academic year. This research is quantitative research. The data is collected by using observation and test. The research sample is students of grade X Mia consisting of 12 students of MAN 2 Mataram. Sample is selected by employing purposive sampling technique. Data analysis used is descriptive statistics. The result shows an average value of 76.25 with a standard deviation of 6.44 , so that the ability to appreciate poetry with hermeneutic methods in mastering the figurative language of students Man 2 Mataram is high.
\end{abstract}

Keywords: hermeneutic method, figurative language, poetry

\begin{abstract}
Abstrak
Tujuan penelitian ini adalah untuk mengetahui kemampuan mengapresiasi puisi dengan metode hermeneutik dalam penguasaan bahasa figuratif siswa di MAN 2 Mataram Tahun Pelajaran 2017/2018. Jenis penelitian yang digunakan adalah penelitian kuantitatif, sedangkan teknik pengumpulan data yang digunakan adalah metode observasi dan metode tes. Sampel dalam penelitian adalah siswa kelas X Mia sebanyak 12 peserta didik di MAN 2 Mataram. Pengambilan sampel dilakukan dengan teknik sampel bertujuan atau purposive sample. Analisis data yang digunakanadalah statistik deskriptif. Hasil penelitian ini adalah nilai ratarata siswa MAN 2 Mataram dalam mengapresiasi puisi dengan metode hermeneutik dalam penguasaan bahasa figuratif adalah 76,25dengan standar deviasi 6,44. Hal ini menunjukkan kemampuan mengapresiasi puisi dengan metode hermeneutik dalam penguasaan bahasa figuratif siswa MAN 2 Mataram terbilang tinggi.
\end{abstract}

Kata kunci: metode hermeneutik, bahasa figuratif, puisi 


\section{Pendahuluan}

Permasalahan yang menyebabkan kualitas pembelajaran sastra menjadi rendah merupakan permasalahan klasik. Sebagaimana yangdiungkapkan oleh Endraswara (2002: 59) bahwa problem pengajaran di sekolah selalu terkait dengan ketersediaan karya sastra, sistem pengajaran, kurikulum yang kurang memberi ruang terhadap sastra, dan kemampuan guru. Bahkan dikatakan bahwa pengajaran sastra di sekolah terkena infeksi, terjangkit virus kronis, suram, dan hampir gagal.Salah satu upaya yang dapat dilakukan guru agar siswa dapat meningkatkan daya apresiasi puisi adalah penggunaan metode herrmeneutik. Metode ini berusaha menafsirkan puisi dengan ilmu hermeneutika. Selain dengan variasi metode, hal lain yang berpengaruh terhadap pembelajaran apresiasi puisi adalah penguasaan bahasa figuratif. Peningkatan kemampuan mengapresiasi puisi dengan metode hermeneutik mustahil dapat berjalan dengan lancar tanpa adanya penguasaan bahasa figuratif yang cukup. Puisi minat sebagai wujud kristalisasi makna dan kepadatan bahasa butuh bekal bahasa figuratif yang lebih dalam penafsirannya.

Berdasarkan latar belakang masalah yang telah dipaparkan di atas, penelitian ini melihat seberapa besar kemampuan siswa dalam mengapresiasi puisi dengan metode hermeneutik dalam penguasaan bahasa figuratif pada siswa kelas X MIA MAN 2 Mataram Tahun Ajaran 2018/2019.

\section{Kerangka Teori}

\section{a. Metode Hermeneutik}

Secara sederhana, hermeneutik berarti tafsir. Dalam kamus Webster's Third New International Dictionary dijelaskan bahwa definisihermeneutik sebagai studi tentang prinsip-prinsip metodologis interpretasi dan eksplanasi, khususnya studi tentang prinsip umum interpretasi Bibel (Palmer, 2005:4). Namun demikian, makna tersebut belum memuaskan bagi para penerjemah Bibel. Abulad (2007:22) menyatakan bahwa hermeneutik sebagai sebuah seni, yaitu seni di dalam menginterpretasikan sebuah teks. Lebih lanjut, ia menyimpulkan bahwa hermeneutik bukan usaha mengkontruksi cara berpikir kaku untuk sebuah interpretasi teks yang sahih, melainkan keluwesan yang menjadi filosofi utamanya.Dari pendapat para ahli tersebut dapat disimpulkan bahwa metode hermeneutik merupakan cara memahami dan manafsirkan sebuah teks dengan merekontruksi proses kreatif teks tersebut. Dalam hermeneutika, proses pemahaman berlangsung dengan tahapan mengungkapkan kata-kata kunci, menjelaskan kata tersebut kemudian menerjemahkannya ke dalam makna yang lebih jelas. 


\section{b. Penguasaan Bahasa Figuratif}

Bahasa figuratif adalah bahasa yang digunakan oleh penyair untuk menyatakan sesuatu dengan cara yang tidak biasa, yakni secara tidak langsung penyair mengungkapkan makna kata atau bahasa bermakna kias atau makna lambang (Waluyo, 1991: 83). Bahasa kias yang biasa terdapat dalam puisi adalah sebagai berikut.

1) Perbandingan/perumpamaan (simile)

Perbandingan atau perumpamaan (simile) ialah bahasa kiasan yang menyamakan satu hal dengan hal yang lain dengan mempergunakan kata-kata pembanding seperti, bagai, semisal, seumpama, laksana, dan kata-kata pembanding lainnya (Wiyatmi, 2005: 67).

2) Metafora

Metafora adalah kiasan yang menyatakan sesuatu sebagai hal yang sebanding dengan hal lain (Wiyatmi, 2005:65). Metafora mempunyai dua unsur, yaitu pembanding (vehiche) dan yang dibandingkan (tenor). Dalam hubungannya dengan kedua unsur tersebut, terdapat dua jenis metafora, yaitu metafora eksplisit dan metafora implisit. Disebut metafora eksplisit apabila unsur pembanding dan yang dibandingkan disebutkan, sedangkan metafora implisit apabila hanya memiliki unsur pembanding (Wiyatmi, 2005:65-66).

3) Personifikasi

Personifikasi adalah kiasan yang menyamakan benda dengan manusia, benda-benda mati dibuat dapat berbuat, berfikir, dan sebagainya seperti manusia (Wiyatmi, 2005: 65).

4) Hiperbola

Kiasan yang berlebih-lebihan. Penyair merasa perlu melebihlebihkan hal yang dibandingkan itu agar mendapat perhatian yang lebih saksama dari pembaca.

5) Metonimia

Bahasa kiasan ini jarang dijumpai pemakaiannya. Metonimia ini dalam bahasa Indonesia sering disebut kiasan pengganti nama. Bahasa ini berupa penggunaan sebuah atribut sebuah objek atau penggunaan sesuatu yang sangat dekat hubungannya dengan penggantian objek tersebut. Metonomia (pengganti 
nama) diartikan sebagai pengertian yang satu dipergunakan sebagai pengertian yang lain berdekatan menurut Luxemburg (Wiyatmi, 2005:66).

6) Sinekdoki (syneadoche)

Sinekdoki adalah bahasa kiasan yang menyebutkan sesuatu bagian yang penting suatu benda (hal) untuk benda atau hal itu sendiri. Sinekdoki merupakan bentuk kiasan yang mirip dengan metonomia, yaitu pengertian yang satu dipergunakan sebagai pengertian lain. Sinekdoki ada dua macam, yaitu

a) Pars prototo, apabila sebagian dipergunakan untuk menyebut atau mewakili keseluruhan; dan

b)Totum proparte, apabila keseluruhan dipergunakan untuk menyebut atau mewakili sebagian (Wiyatmi, 2005:67).

7) Allegori

Alegori adalah cerita kiasan ataupun lukisan kiasan. Cerita kiasan atau lukisan kiasan ini mengiaskan hal lain atau kejadian lain.

\section{c. Unsur-Unsur Pembangun Puisi}

Unsur-unsur pembangun puisi dapat terdiri atas beberapa unsur, diantaranya:

1) Diksi (Pilihan Kata)

Diksi adalah sebuah pilihan kata yang tepat dan selaras (dalam penggunaannya) untuk mengungkapkan gagasan sehingga diperoleh efek tertentu (seperti yang diharapkan).

\section{2) Bahasa Figuratif}

Bahasa figuratif adalah bahasa yang digunakan oleh penyair untuk menyatakan sesuatu dengan cara yang tidak biasa, yakni secara tidak langsung penyair mengungkapkan makna kata atau bahasa bermakna kias atau makna lambang (Waluyo, 1991: 83).

Bahasa kias yang biasa terdapat dalam puisi adalah sebagai berikut
a) perbandingan/ perumpamaan (simile);
b) metafora,
c) personifikasi,
d) hiperbola,
e) metonimia, dan
e) sinekdok (syneadoche).

\section{3) Metode Penelitian}

Penelitianini menggunakan pendekatan kuantitatif yang memerlukan perhitungan dengan menggunakan angka serta memakai analisis statistik. Pendekatan kuantitatif adalah suatu 
poses menemukan pengetahuan yang menggunakan data berupa angka sebagai alat menemukan keterangan mengenai apa yang ingin kita ketahui (Margono, 1997:105).

\section{a. Populasi}

Populasi adalah keseluruhan subjek penelitian yang mempunyai karakteristik tertentu dalam suatu peneltian. Populasi dalam penelitian ini berjumlah 68 peserta didik yang terdiri atas kelas $\mathrm{X}$ sebanyak99 orang, kelas XI sebanyak120 orang, dan kelas XII= sebanyak130 orang peserta didik di MAN 2 Mataram Tahun Pelajaran 2017/2018.

\section{b. Sampel}

Margono (1997:121) mengatakan sampel adalah sebagian dari populasi yang diambil dari cara-cara tertentu.Teknik pengambilan sampel yang digunakan dalam penelitian ini adalah teknik sampel bertujuan (purposive sample). Adapun yang menjadi sampel dalam penelitian ini adalah peserta didik kelas X Mia sebanyak 12 orang.

\section{c. Teknik Pengumpulan Data}

Metode pengumpulan data yang digunakan dalam penelitian ini adalah sebagai berikut.

\section{1) Observasi}

Observasi merupakan kegiatan pemusatan perhatian terhadap suatu objek dengan menggunakan seluruh alat indera
(Arikunto, 1997:133). Metode ini digunakan untuk memperoleh informasi dan fakta-fakta yang berkaitan untuk memahami karakter peserta didik sebagai sampel penelitian secara detail. Tujuannya untuk mendapatkan data primer responden yang menyangkut tentang pengaruh metode hermeneutik dalam meningkatkan kemampuan mengapresiasi puisi peserta didik.

2) Tes Kemampuan Menulis

Tes merupakan suatu cara untuk mengadakan penilaian yang berbentuk suatu tugas dan serangkaian tugas yang harus dikerjakan oleh anak atau kelompok anak sehingga menghasilkan suatu nilai tentang tingkah laku atau prestasi anak tersebut. Menulis adalah kegiatan menyampaikan pesan (gagasan, perasaan dan informasi secara tertulis pada pihak lain (Akhadiah, 1997:116) sebagai salah satu bentuk komunikasi verbal. Menulis melibatkan unsur penulis sebagai penyampai pesan atau tulisan, saluran atau medium tulisan, dan pembaca sebagai penerima pesan, sedangkan puisi dapat diartikan "membuat atau pembuatan" karena lewat puisi pada dasarnya seseorang telah menciptakan suatu dunia tersendiri yang mungkin berisi pesan dan gambaran-gambaran suasanasuasana tertentu, baik fisik maupun batiniah (Aminudin, 1995:135).

Di dalam menulis puisi, ada hal-hal yang perlu diperhatikan, di antaranya

a. diksi atau pilihan kata 
b. gaya bahasa

c. makna

Dalam tes kemampuan menulis puisi ini, penulis menilai kemampuan menulis peserta didik dari beberapa aspek.Kriteriakriteria penilaian seperti yang terlihat dalam tabel di bawah ini

\section{Tabel 1}

Kriteria-Kriteria Penilaian

\begin{tabular}{|c|l|c|}
\hline No. & $\begin{array}{l}\text { Aspek Penilaian/Aspek Yang } \\
\text { Dinilai }\end{array}$ & Skor \\
\hline 1. & $\begin{array}{l}\text { Puisi tersebut sesuai dengan } \\
\text { temanya }\end{array}$ & 25 \\
2. & $\begin{array}{l}\text { Pemilihan kata-kata sesuai } \\
\text { 3. }\end{array}$ & 25 \\
Gaya bahasa yang digunakan & 20 \\
4. & $\begin{array}{l}\text { Maknarik } \\
\text { menarik }\end{array}$ & 15 \\
5. & Amangat dalam puisi & 15 \\
\hline \multicolumn{2}{|||}{ Jumlah } & 100 \\
\hline
\end{tabular}

\section{d. Metode Analisis Data}

Kegiatan peserta dapat diketahui apabila observasi dilakukan terhadap perilaku peserta didik selama mengikuti proses pembelajaran. Observasi yang dilakukan harus berpedoman pada indikatorindikator yang sudah ditetapkan sebelumnya. Aktivitas peserta didik dianalisis secara deskriptif. Adapun cara yang digunakan dalam teknik ini adalah sebagai berikut.

1) Menentukan skor rata-rata aktivitas belajar peserta didik
Dalam menentukan skor rata-rata aktivitas belajar peserta didik, digunakan rumus sebagai berikut:

$\mathrm{A}=\frac{\Sigma T}{N}$

Keterangan :

A =Mean (skor rata-rata aktivitas belajar peserta didik)

$\sum \mathrm{T}=$ Total skor aktivitas belajar seluruh peserta didik

$\mathrm{N}$ =Banyak peserta didik

2) Menganalisis aktivitas belajar peserta didik

Data tentang aktivitas belajar peserta didik dianalisis secara deskriptif kualitatif dengan menggunakan skala 1--5. Indikator tentang aktivitas belajar peserta didik yang diamati adalah sebanyak 5 indikator dengan skor maksimal 5.Dengan demikian, skor maksimal ideal (SMi) adalah 5 x $5=25$. Setiap indikator memiliki 4 deskriptor. Skor 5 diberikan jika semua deskriptor teridentifikasi, skor 4 diberikan jika tampaktiga deskripstor, skor 3 diberikan jika tampak dua deskriptor, skor 2 diberikan jika hanya tampak satu deskriptor,dan sekor 1 diberikan jika tidak tampak satu pun deskriptor.

3) Menganalisis data

Analisis data aktivitas belajar peserta didik yang digunakan adalah Mi (mean ideal) dan SDi (Standar Deviasi ideal). 


$$
\begin{array}{rlr}
\mathrm{Mi} & =\frac{1}{2} \times(\mathrm{SMi}) \\
& =\frac{1}{2} \times(25) \\
& =\frac{1}{3}, 5 \\
\mathrm{SDi} & =\frac{1}{3} \times(12,5)=4,17
\end{array}
$$

Berdasarkan skor standar, kriteria untuk menentukan aktivitasbelajar peserta didik dijabarkan pada tabel berikut ini

\section{Tabel 2}

Pedoman Konversi Penilaian Skala 1--5

\begin{tabular}{|l|c|l|}
\hline \multicolumn{1}{|c|}{ INTERVAL } & NILAI & KRITERIA \\
\hline $\begin{array}{l}\mathrm{Mi}+1,5 \mathrm{SDi} \leq \\
\mathrm{A}\end{array}$ & $\mathrm{A} \geq 18,75$ & Sangat aktif \\
\hline $\begin{array}{l}\mathrm{Mi}+0,5 \mathrm{Sdi} \leq \mathrm{A} \\
<\mathrm{Mi}+1,5 \mathrm{Sdi}\end{array}$ & $\begin{array}{c}14,58 \leq \mathrm{A} \\
<18,75\end{array}$ & Aktif \\
\hline $\begin{array}{l}\mathrm{Mi}-0,5 \mathrm{SDi} \leq \mathrm{A} \\
<\mathrm{Mi}+0,5 \mathrm{Sdi}\end{array}$ & $\begin{array}{c}10,42 \leq \mathrm{A} \\
<14,58\end{array}$ & Cukup aktif \\
\hline $\begin{array}{l}\mathrm{Mi}-1,5 \mathrm{SDi} \leq \mathrm{A} \\
<\mathrm{Mi}-0,5 \mathrm{Sdi}\end{array}$ & $\begin{array}{c}6,25 \leq \mathrm{A}< \\
10,42\end{array}$ & $\begin{array}{l}\text { Kurang } \\
\text { aktif }\end{array}$ \\
\hline $\begin{array}{l}\mathrm{A} \leq \mathrm{Mi}-1,5 \\
\mathrm{Sdi}\end{array}$ & $\mathrm{A} \leq 6,25$ & $\begin{array}{l}\text { Sangat } \\
\text { kurang aktif }\end{array}$ \\
\hline
\end{tabular}

Untuk data aktivitas peserta didik dikatakan berhasil apabila rata-rata skor aktivitas belajar peserta didik minimal berkategori aktif.

\section{Pembahasan}

Pelaksanaan pembelajaran metode hermeneutik dalam penguasaan bahasa figuratif dimulai dengan meminta izin kepada guru bidang studi bahasa Indonesia dalam materi pokok mengapresiasi puisi, kemudian peneliti menyesuaikan dengan jam pelajaran yang ada di kelas. Yang menjadi sampel dalam penelitian ini yaitu kelas $\mathrm{X}$ MIA MAN 2 Mataram.Dalam pelaksanaan pengumpulan data, digunakan dua metode yaitu, observasi dan tes. Berikut ini akan diuraikan dari masing-masing metode tesebut.

\section{a. Pelaksanaan Metode Observasi}

Dengan melihat dan memahami tentang keberadaan Kelas X MIA MAN 2 Mataram, ternyata di dalamnya terdapat perubahan dan kerja yang cukup pesat. Tolak ukur dari hal tersebut adalah pembelajaran bagi peserta didik terakomodasi dan termotivasi dengan baik. Dengan demikian, dapat dikatakanbahwa tingkat penguasaan yang dicapai oleh peserta didik dalam mengikuti program hermeneutik sesuai dengan tujuan yang diharapkan dan prestasi belajar bahasa Indonesia cukup memuaskan. Pemahaman peserta didik tentang materi yang diberikan oleh guru dapat dilihat dari berhasil tidaknya peserta didik dalam mengerjakan tugas rumah yang diberikan oleh guru. Untuk mencapai hal itu tidak mudah karena tugas rumah adalah salah satu faktor yang dapat mendukung tercapainya prestasi belajar peserta didik (Observasi, 19 April 2018). 
Untuk mengetahui hasil dari tes siswa terhadap metode hermeneutik dalam penguasaan bahasa figuratif pada kemampaun mengapresiasikan puisi pada peserta didik kelas $\mathrm{X}$ MIA MAN 2 Mataram bidang studi bahasa Indonesia, peneliti telah mengadakan observasi sebelumnya dalam kegiatan proses belajar mengajar. Di samping itu, penulis melakukan penyebaran tes dengan meminta izin kepada guru bidang studi setelah proses pembelajaran selesai.

\section{b. Pelaksanaan Tes}

Dengan metode tes, terkumpul data tentang hasil sampel dalam mata pelajaran yang diajarkan. Tes dilakukan setelah proses pembelajaranselesai.Jumlah skor dibagi sesuai dengan jumlah aspek dalam puisi. Dalam menentukan skor rata-rata aktivitas belajar peserta didik, dinilai dengan menggunakan rumus sebagai berikut:

$$
\mathrm{Y}=\frac{\Sigma T}{N} \quad=\frac{915}{12}=76.25
$$

\subsection{Nilai KemampuanMengapresiasikan} Puisi dengan metode Hermenutik

Hasil penjumlahan nilai rata-rata dengan jumlah 76.25 dengan rincian yaitu keseluruhan skor test 915 dibagi jumlah responden (12) dapat dilihat pada tabel berikut.

\section{Tabel 3}

Nilai Kemampuan Mengapresiasikan Puisi dengan Menggunakan Metode Hermeneutik

\begin{tabular}{|c|c|c|c|c|c|c|}
\hline \multirow[b]{2}{*}{ Nama Siswa } & \multicolumn{5}{|c|}{ Skor Masing-Masing Aspek } & \multirow[b]{2}{*}{$\begin{array}{c}\text { Jumlah } \\
\text { Skor }\end{array}$} \\
\hline & Tema & Diksi & $\begin{array}{c}\text { Gaya } \\
\text { Bahasa }\end{array}$ & Makna & Amanat & \\
\hline $\begin{array}{l}\text { Abel } \\
\text { FahrezaHaris }\end{array}$ & 15 & 15 & 14 & 13 & 13 & 70 \\
\hline Aina Tajria & 15 & 20 & 15 & 15 & 15 & 80 \\
\hline $\begin{array}{l}\text { Athaya } \\
\text { Salsabila }\end{array}$ & 15 & 20 & 20 & 15 & 20 & 90 \\
\hline $\begin{array}{l}\text { Didik } \\
\text { Arifandi }\end{array}$ & 15 & 15 & 14 & 13 & 13 & 70 \\
\hline Fadila Aulia & 20 & 15 & 15 & 15 & 15 & 80 \\
\hline Fira Lutfiana & 15 & 14 & 13 & 14 & 14 & 70 \\
\hline $\begin{array}{l}\text { Haekal Ali } \\
\text { An }\end{array}$ & 17 & 17 & 16 & 15 & 15 & 80 \\
\hline $\begin{array}{l}\text { Hartadi } \\
\text { Rahman }\end{array}$ & 18 & 18 & 14 & 15 & 15 & 80 \\
\hline Nuron Ismi & 15 & 20 & 15 & 15 & 15 & 80 \\
\hline $\begin{array}{l}\text { Olyvia } \\
\text { Adnin }\end{array}$ & 15 & 15 & 15 & 15 & 15 & 75 \\
\hline $\begin{array}{l}\text { Riska } \\
\text { Maulidina }\end{array}$ & 15 & 14 & 13 & 14 & 14 & 70 \\
\hline Rozana & 15 & 14 & 13 & 14 & 14 & 70 \\
\hline \multicolumn{6}{|c|}{ Jumlah } & $\sum=915$ \\
\hline & & & & & & $\begin{array}{l}Y^{2}= \\
70225\end{array}$ \\
\hline \multicolumn{6}{|c|}{ Rata - Rata } & 76.25 \\
\hline
\end{tabular}

1) Nilai perhitungan test

Data yang diolah adalah

a. Rentangan

$$
\begin{aligned}
& \mathrm{R}=\text { skor terbesar }- \text { skor terkecil } \\
& \mathrm{R}=90-70=20
\end{aligned}
$$

b. Nilai Rata-Rata

$$
\text { Mean }=s_{t}^{2}=\frac{915}{12}=76.25
$$

c. Standar Deviasi 
Tabel 4

Klasifikasi Jumlah Skor dengan Menggunakan Metode Hermeneutik

\begin{tabular}{|c|c|c|c|}
\hline Klasifikasi & $\begin{array}{c}\text { Jumlah } \\
\text { Peserta } \\
\text { didik }\end{array}$ & $\begin{array}{c}\text { Frekwensi } \\
(\%)\end{array}$ & $\begin{array}{c}\text { Keterangan } \\
\text { skor }\end{array}$ \\
\hline $67-70$ & $\begin{array}{c}5 \\
\text { Peserta } \\
\text { didik }\end{array}$ & 41.67 & Sedang \\
\hline $71-75$ & $\begin{array}{c}1 \\
\text { Peserta } \\
\text { didik }\end{array}$ & 8.33 & Tinggi \\
\hline $76-80$ & $\begin{array}{c}5 \\
\text { Peserta } \\
\text { didik }\end{array}$ & 41.67 & Tinggi \\
\hline $81-90$ & $\begin{array}{c}1 \\
\text { Peserta } \\
\text { didik }\end{array}$ & 8.33 & Tinggi \\
\hline Jumlah & 12 & $100 \%$ & \\
\hline
\end{tabular}

$$
\begin{gathered}
s=\sqrt{\frac{\sum x^{2}-\frac{\left(\sum x\right)^{2}}{n-1}}{12-1}}= \\
s=\sqrt{\frac{70225-\frac{(915)^{2}}{12}}{12-\frac{70225-\frac{(837225)}{12}}{12-1}}}= \\
s=\sqrt{\frac{70225-69768.75}{11}=6.44}
\end{gathered}
$$

Jadi, standar deviasi hasil nilai adalah 6.44. d. Varian

Varian merupakan akar kuadrat dari standar deviasi.

$$
=6.44^{2}=41.48
$$

Selanjutnya, hasil nilai tes peserta didik dipaparkan. Klasifikasi jumlah skor jawaban peserta didik dari hasil kemampuan peserta didik mengapresiasikan puisi kelas X MIA MAN 2 Mataram bidang studi bahasa Indonesia dapat dilihat pada tabel berikut ini.

Berdasarkan hasil tabel di atas, kemampuan peseta didik dalam mengapresiasikan puisi dengan metode hermeneutic dianggap sedang, yakni antara 67--70 sebanyak 5 peserta didik, sedangkan yang dianggap sedang yakni antara 71--75 sebanyak 1 peserta didik, sedangkan yang dianggap tinggi yakni antara 76--80 sebanyak 5 peserta didik, sementara peserta didik yang mendapatkan nilai tinggi, yakni antara 81--90 sebanyak 1 peserta didik.

\section{Penutup}

Berdasarkan data yang diperoleh dari hasil analisis dan hasil pembahasan dengan menggunakan rumus nilai rata-rata 76,25 dan standar deviasi 6,44 dan dengan varian akar kuadrat dari standar deviasi 41.48, dapat disimpulkan bahwa kemampuan peserta didik 
dalam mengapresiasi puisi dengan metode hermeneutik dalam penguasaan bahasa figuratif di Kelas MIA MAN 2 Mataram Tahun Pelajaran 2017/2018 masuk dalam kategori sangat aktif.

Bertitik tolak pada simpulan yang didapatkan dari hasil penelitian di atas, dapat disarankan beberapa hal sebagai berikut.

a. Madrasah sebagai lembaga penyelenggara pendidikan agar lebih meningkatkan serta mengedepankan kualitas guru sebagai top leader agar tujuan pendidikan dapat tercapai sesuai dengan target yang diharapkan.

b. Guru bahasa Indonesia agar dapat lebih mengoptimalkan kualitas pembelajaran dengan menerapkan metode pembelajaran yang relevan dengan materi yang dibahas, misalnya dengan rancangan metode hermeneutik dalam penguasaan bahasa figuratif sebagai salah satu alternatif metode pembelajarannya.

c. Peneliti yang berminat pada masalah yang sama disarankan agar meneliti secara lebih mendalam pada aspek-aspek yang belum terjangkau dalam penelitian ini.

\section{Daftar Pustaka}

Abulad, Romualdo E.(2007). "What is Hermeneutics?”. Dalam Kritike. Vol. 1 No. 2 Desember.

Aminuddin. (2011). Pengantar Apresiasi Karya Sastra. Malang: Sinar Baru Algensindo Bandung.

Arikunto, Suharsimi. (2006). Penelitian Tindakan Kelas. Jakarta: Bumi Aksara.

Furman, Richard. (2007). Poetry Narrative as Qualitative Data: Exploration into Existential Theory. Dalam IndoPacific Journal of Phenomenology, Volume 7, Edition 1 May.

Geisler, Deborah M. (1985). "Modern Interpretation Theory and Competitive Forensics: Understanding Hermenutics Text". Dalam The National Forensics Journal.

Herman. J. Waluyo. (1995). Teori dan Apresiasi Puisi. Jakarta. Penerbit Erlangga.

Husaini dkk. (2004). Metodologi Penelitian Sosial. Jakarta: Bumi Aksara.

Margono. (1997). Metodologi Penelitian Pendidikan. Jakarta : PT.Rineka Cipta.

Palmer, Richard E.2005. Hermeneutika: Teori Baru Mengenal Interpretasi (terjemahan: Musnur Hery dan Damanhuri Muhammad). Yogyakarta: Press.

Sugiyono, (2006). Metode Penelitian Kuantitatif Kualitatif dan $R \& D$. Alfabeta, Bandung. 
195 | Mabasan, Vol. 12, No. 2, Juli--Desember 2018: 185--195

Tirto, Suwondo. (2001). Metodologi Penelitian Sastra (Editor: Jabrohim dan Ari Wulandari). Yogyakarta: Hanindita Graha W.

Wiyatmi. (2005). Pengantar Kajian Sastra. Yogyakarta: Puataka. 